\title{
ANALISIS SISTEM INFORMASI AKUNTANSI \\ PENERIMAAN KAS DARI PENJUALAN TUNAI GUNA MENINGKATKAN PENGENDALIAN INTERN PT. INDOMARCO PRISMATAMA
}

\author{
(INDOMARET STADION PLANDAAN \\ KEDUNGWARU TULUNGAGUNG)
}

\begin{abstract}
MOHAMMAD KHUBBI NUR AMAMI, ATALYA PERMATA PUTRI ZADOK, DEVI
\end{abstract}
RO'AYUN NURFARIDA

Prodi Akuntansi, Fakultas Ekonomi, Universitas Tulungagung (UNITA)

\begin{abstract}
ABSTRAK
Penelitian ini bertujuan untuk mengetahui penerapan sistem informasi akuntansi kegiatan penerimaan kas untuk meningkatkan pengendalian intern pada PT. Indomarco Prismatama (Indomaret Stadion Plandaan Kedungwaru Tulungagung). Objek Penelitian ini adalah perusahaan dagang francise (waralaba) Jenis data yang digunakan adalah data primer dan data sekunder. Pengambilan data dilakukan melalui survey pendahuluan, penelitian lapangan, yaitu observasi, interview, dan dokumentasi. Penelitian ini menggunakan metode analisis dekriptif kualitatif Berdasarkan analisis yang dilakukan diketahui bahwa untuk sistem informasi akuntansi penjualan dan penerimaan kas, perusahaan sudah memiliki unsur pengendalian intern yang baik. Walaupun masih ditemukan beberapa masalah, diantaranya masih terdapat perangkapan fungsi oleh Asisten Kepala Toko, kas tidak langsung disetor ke bank.
\end{abstract}

Kata Kunci: Sistem Informasi Akuntansi, Penerimaan Kas, Penjualan Tunai, Pengendalian Internal. 


\begin{abstract}
ABTRACK
The purpose of the study is to understand the implementation an accounting information system activities of the cash receipts to support the internal control on PT. Indomarco Prismatama (Indomaret Plandaan Kedungwaru Tulungagung). The study object is the trading company franchise (franchise). Types of data used are primary data and secondary data. Data were collected through a preliminary survey, field research, observation, interviews, and documentation. This study is using descriptive qualitative analysis method.Based on the analysis known that the information's system of accounting for cash receipt at this mini market has been have well intern control. Altough there were many problem has found, that is still there double function by Assisten Store, still found the difference between price tag and POS, petty cash didn't deposited directly to bank.
\end{abstract}

Keyword: Accounting Information System, Cash Receipts, Cash Sales, Internal control 


\section{PENDAHULUAN}

Perkembangan dalam dunia usaha ditandai pula oleh adanya perkembangan dalam ruang lingkup aktivitas perusahaan dan sistem informasi yang digunakan. Pengembangan sistem (systems development) merupakan menyusun suatu sistem yang baru untuk menggantikan sistem yang lama secara keseluruhan atau memperbaikis istem yang telah ada. Sistem yang lama perlu diperbaiki atau diganti disebabkan karena beberapa hal, yaitu :1. Adanya permasalahan-permasalahan (problems) yang timbul di sistem yang lama ; 2. Ketidakberesan dalam sistem yang lama menyebabkan sistem yang lama tidak dapat beroperasi sesuai dengan yang diharapkan; 3. Kecurangan-kecurangan disengaja yang menyebabkan tidak amannya harta kekayaan perusahaan dan kebenaran dari data menjadi kurang terjamin ; 4. Kesalahankesalahan yang tidak disengaja yang juga dapat menyebabkan kebenaran dari data kurang terjamin ; 5. Tidak efisiennya operasi.; 6. Tidak ditaatinya kebijaksanaan manajemen yang telah ditetapkan.(Gesah \& Prabowo, 2015)

Peran dari sistem informasi terhadap kemajuan dari sebuah perusahaan sudah tidak diragukan lagi. Dengan dukungan sistem informasi yang baik maka sebuah perusahaan akan mempunyai keunggulan kompetitif sehingga mampu bersaing dengan perusahaan yang lain.

Kemajuan dan pemanfaatan teknologi informasi sangat pesat dengan menerapkan teknologi informasi dan komunikasi, diharapkan dapat membantu manajemen dalam menghimpun data, dan menghasilkan informasi sehingga dapat meningkatkan efektivitas dan efesiensi tindakan majamen dalam pengambilan keputusan yang didasarka informasi yang dihasilkan.

Sistem informasi akuntansi memiliki beberapa sistem bagian (sub-system) yang berupa siklus transaksi akuntansi. Lima siklus transaksi akuntansi yaitu : siklus pembiayaan, siklus pendapatan, siklus pengeluaran, siklus produksi dan siklus penggajian. Siklus pendapatan terdiri dari semua aktivitas penjualan dan penerimaan kas. Sistem informasi akuntansi penjualan dan penerimaan kas yang baik merupakan salah satu upaya dalam meningkatkan pengendalian intern perusahaan. Diperlukan suatu sistem pengendalian intern yang berfungsi untuk membantu dan menjaga keamanan harta milik perusahaan, menjamin ketelitian dan kebenaran data, memajukan efisiensi dalam 
operasi kegiatan perusahaan serta dipatuhinya kebijakan manajemen yang telah ditetapkan.

PT. Indomarco Prismatama (Indomaret Stadion Plandaan Kedungwaru Tulungagung) merupakan jaringan minimarket di Indonesia yang menyediakan kebutuhan pokok dan kebutuhan sehari-hari. Adapun permasalahan yang dihadapi adalah belum diterapkannya sistem dan prosedur penjualan dan penerimaan kas yang memadai. Hal ini terlihat dari adanya perangkapan fungsi pada bagian-bagian yang terkait. Perbedaan Slip penjualan dengan uang kas secara fisik dari penjualan tunai yang diterima. Dan juga adanya perbedaan harga antara price list yang ada di rak produk dengan harga yang tertera di POS (Point Of Sales) di kasir menandakan lemahnya sistem internal kontrol pada penjualan tunai. Berdasarkan masalah tersebut, maka menarik minat peneliti untuk mengajukan judul “Analisis Sistem Informasi Akuntansi Penerimaan Kas dari Penjualan Tunai Guna Meningkatkan Pengendalian Intern PT. Indomarco Prismatama (Indomaret Stadion Plandaan Kedungwaru Tulungagung)" 


\section{LANDASAN TEORI}

\subsection{Definisi Sistem Informasi Akuntansi}

Menurut (Susanto, 2013), sistem adalah kumpulan dari sub sistem, bagian, unsur, komponen apapun baik fisik maupun non fisik yang saling berhubungan satu sama lain dan bekerjasama secara harmonis untuk mencapai satu tujuan. Dengan demikian sistem merupakan sekelompok unsur yang erat berhubungan satu dengan lainnya, yang berfungsi bersama-sama untuk mencapai tujuan tertentu, yang dibuat untuk menangani sesuatu yang berulang kali atau yang secara rutin terjadi.

Dalam suatu organisasi ada 3 sistem, yang berperan sebagai pedoman yaitu:

1. Sistem Informasi, yaitu dalam bentuk sistem informasi akuntansi dan sistem informasi manajemen.

2. Sistem Operasi, yaitu dalam bentuk proses bisnis dan fungsi bisnis

3. Sistem Pengendalian, yaitu dalam bentuk fungsi manajemen yang dapat berperan mengendalikan sistem informasi dan sistem operasi.

Informasi adalah sekumpulan pesan yang terdiri dari order sekuens dari simbol, atau makna yang dapat ditafsirkan dari pesan atau kumpulan pesan. Informasi bisa di katakan sebagai pengetahuan yang didapatkan dari pembelajaran, pengalaman, atau instruksi.

Sistem Informasi adalah kombinasi dari teknologi informasi dan aktivitas orang yang menggunakan teknologi itu untuk mendukung operasi dan manajemen. Dalam arti yang sangat luas, istilah sistem informasi yang sering digunakan merujuk kepada interaksi antara orang, proses algoritmik, data, dan teknologi.

Akuntansi adalah kegiatan pengukuran, pencatatan, penghitungan, penjabaran, atau pemberian kepastian mengenai informasi yang akan membantu manajer, investor, otoritas pajak dan pembuat keputusan lain untuk membuat alokasi sumber daya keputusan di dalam perusahaan, organisasi, dan lembaga pemerintah.

Sistem akuntansi adalah informasi yang berhubungan dengan data finansial terutama informasi keuangan. Untuk memenuhi kebutuhan informasi bagi pihak luar maupun dalam perusahaan, disusun suatu sistem akuntansi yang dapat diproses dengan cara manual (tanpa 
mesin pembantu) atau diproses dengan menggunakan mesin pembukuan sederhana sampai dengan komputer.

Menurut (Mulyadi, 2016) menyatakan, Sistem Informasi Akuntansi adalah organisasi formulir, catatan, dan laporan yang di koordinasi sedemikian rupa untuk menyediakan informasi keuangan yang dibutuhkan oleh manajemen guna memudahkan pengelolaan perusahaan. Pada penyusunannya, sistem informasi akuntansi harus mampu menyediakan informasi yang diperlukan dengan cepat dan tepat waktu serta dapat memenuhi kebutuhan pengguna, sistem informasi akuntansi juga harus dapat membantu menjaga keamanan harta milik perusahaan, dan dibuat dengan penekanan biaya sehingga penyusunan sistem relatif tidak mahal. Sistem informasi akuntansi juga terbagi dalam lima subsistem, yaitu :

Sistem pengeluaran (expenditure system). Adalah segala peristiwa yang berhubungan dengan usaha mendapatkan sumber - sumber ekonomis yang diperlukan perusahaan.

Sistem pendapatan (revenue system). Adalah sistem informasi akuntansi yang berhubungan dengan penjualan barang atau jasa yang dihasilkan oleh perusahaan untuk konsumen dan mendapatkan pembayaran dari mereka.

Sistem produksi (production system). Adalah sistem informasi akuntansi yang berhubungan dengan proses mengumpulkan, menggunakan, dan merubah bentuk suatu sumber ekonomi.

Sistem manajemen sumber daya (resources management system). Adalah sistem informasi akuntansi yang meliputi berbagai hal yang berkenaan dengan manajemen dan pengendalian sumber daya

> Sistem buku besar dan laporan keuangan (general ledger and financial accounting). Adalah sistem informasi yang meliputi proses pengolahan bukti- bukti keuangan dan laporan keuangan yang mewakili status financial perusahaan. 


\subsection{Tujuan Sistem Informasi Akuntansi}

Menurut (Romney, 2014) Tujuan Sistem Informasi Akuntansi ada tiga yaitu :

Untuk mendukung fungsi kepengurusan (stewardship) manajemen suatu organisasi atau perusahaan, karena manajemen bertanggung jawab untuk menginformasikan pengaturan dan penggunaan sumber daya organisasi dalam rangka pencapaian tujuan organisasi tersebut.

Untuk mendukung pengambilan keputusan manajemen, karena sistem informasi memberikan informasi yang diperlukan oleh pihak manajemen untuk melakukan tanggung jawab pengambilan keputusan.

Untuk mendukung kegiatan operasional perusahaan hari demi hari.

\subsection{Fungsi Sistem Informasi Akuntansi}

Menurut (Romney, 2014) fungsi Sistem Informasi Akuntansi yaitu:

Mengumpulkan dan menyimpan data mengenai aktivitas, sumber daya dan personel organisasi. Organisasi memiliki sejumlah proses bisnis, seperti melakukan penjualan atau pembelian bahan baku yang sering diulang.

Mengubah data menjadi informasi sehingga manajemen dapat merencanakan, mengeksekusi, mengendalikan, dan mengevaluasi aktivitas, sumber daya dan personel.

Memberikan pengendalian yang memadai untuk mengamankan aset data organisasi atau perusahaan

Mengumpulkan dan menyimpan data tentang aktivitas - aktivitas yang dilaksanakan oleh organisasi agar pihak manajemen, pegawai dan pihak pihak luar yang berkepentingan dapat meninjau ulang hal-hal yang telah terjadi. 
Mengubah data menjadi informasi yang berguna bagi pihak manajemen untuk membuat keputusan dalam aktivitas perencanaan, pelaksanaan dan pengawasan.

Menyediakan pengendalian yang memadai untuk menjaga aset-aset organisasi termasuk data organsiasi, untuk memastikan bahwa data tersebut tersedia saat dibutuhkan, akurat dan handal

\subsection{Komponen-komponen Sistem Informasi Akuntansi}

Menurut ( R o m ney, 2014 ), unsur-unsur sistem informasi akuntansi terbagi menjadi lima, yaitu :

$>$ Orang - orang yang menggunakan system

Prosedur - prosedur yang digunakan untuk mengolah data

Data mengenai organisasi dan aktivitas bisnisnya

$>$ Perangkat lunak (software) yang digunakan untuk mengolah data.

> Infrastruktur teknologi informasi, meliputi komputer, perangkat periferal dan perangkat jaringan komunikasi yang digunakan dalam sistem informasi akuntansi.

\subsection{Siklus-siklus Pemrosesan Akuntansi}

> Siklus pendapatan: Kejadian-kejadian yang berkaitan dengan pendistribusian barang dan jasa kepada entitas-entitas lain dan penagihan pembayaran yang berkaitan.

Siklus pengeluaran: Kejadian-kejadian yang berkaitan dengan perolehan barang dan jasa dari entitas-entitas lain dan pelunasan kewajiban-kewajiban yang berkaitan.

Siklus produksi: Kejadian-kejadian yang berkaitan dengan pengubahan sumber daya menjadi barang dan jasa.

Siklus keuangan: Kejadian-kejadian yang berkaitan dengan perolehan dan manajemen dana-dana modal, termasuk kas Siklus pemrosesan transaksi terdiri dari satu atau lebih sistem aplikasi. 


\subsection{Konsep Sistem Pengolahan Transaksi Keuangan}

Transaksi keuangan dalam perusahaan terjadi dikarenakan aktivitas yang berhubungan dengan pihak luar perusahaan dalam pertukaran ekonomi dengan pihak-pihak eksternal tersebut saat penjualan barang dan jasa, pembelian persediaan, pembebanan kewajiban keuangan dan penerimaan kas dari pelanggan.

Siklus akuntansi adalah proses pencatatan akuntansi dari seluruh transaksi (aktivitas perusahaan) mulai dari transaksi awal (penerimaan dan pengeluaran uang secara tunai atau kredit), pencatatan buku besar (posting), menyusun neraca saldo, ayat jurnal penyesiaan sampai penyusunan laporan keuangan.

Siklus akuntansi terdiri dari dua bagian yang saling terkait antara lain: tahap pencatatan dan tahap pelaporan.

\subsubsection{Tahap Pencatatan}

Melakukan transaksi (aktivitas). Analisis atau dokumen aktivitas binis menjadi dasar untuk pencatatan awal setiap transaksi.

Mencatat transaksi dalam jurnal. Berdasarkan dokumen pendukung, transaksi dicatat dengan menggunakan ayat atau entri jurnal secara kronologis pada awal setiap transaksi.

Memindah bukukan (posting) transaksi kedalam buku besar (ledger). Transaksi yang telah dikelompokkan dan dicatat pada jurnal diposting pada akun - akun yang sesuai dengan buku besar (general ledger) dan apabila diperlukan pada buku tambahan atau buku pembantu (subsidiary ledger).

\subsubsection{Tahap Pelaporan}

Menyiapkan neraca saldo atau neraca percobaan (trial balance) atas akun-akun dibuku besar.

Neraca saldo berisi daftar setiap akun pada buku besar bersama saldo debit dan kreditnya. 
Mencatat jurnal penyesuaian : Sebelum laporan keuangan disiapkan, semua informasi relevan yang belum tercatat harus diidentifikasi dan dibuatkan penyesuaian yang tepat.

Menyiapkan laporan keuangan : Laporan ini merupakan ikhtisar hasil operasi dari aktivitas perusahaan dan menunjukkan posisi keuangan serta arus kas yang disiapkan berdasarkan informasi yang terdiri dari akun yang telah disajikan.

Menutup akun nominal: Saldo-saldo akun nominal (sementara) ditutup ke akun laba ditahan. Proses penutupan ini mengakibatkan akun nominal bersaldo nol (0) pada awal periode berikutnya.

Menyiapkan neraca saldo setelah penutupan atau neraca penutup (post closing trial balance) untuk memastikan kesamaan atau keseimbangan debit dan kredit setelah jurnal penyesuaian dan jurnal penutup diposting.

\subsection{Sistem Informasi Akuntansi}

Sering kali dikatakan bahwa akuntansi adalah bahasa dunia bisnis. Jika ini masalahnya, maka sistem informasi akuntansi (SIA- accounting information system) adalah kecerdasan penyedia informasi dari bahasa bisnis tersebut. sistem informasi akuntansi adalah organisasi formulir, catatan, dan laporan yang dikoordinasikan sedemikian rupa untuk menyediakan informasi keuangan yang dibutuhkan oleh manajemen guna memudahkan pengelolaan perusahaan. (Mulyadi, 2016)

Istilah sistem informasi akuntansi meliputi pemanfaatan teknologi informasi untuk menyediakan informasi bagi para pemakai. Komputer digunakan pada seluruh jenis sistem informasi. Teknologi informasi mencakup komputer, tetapi juga mencakup teknologi yang lain yang digunakan untuk memproses informasi. 


\subsection{Sistem Penerimaan Kas dari Penjualan Tunai}

Penjualan tunai dilaksanakan oleh perusahaan dengan cara mewajibkan pembeli melakukan pembayaran harga barang lebih dahulu sebelum barang diserahkan oeh perusahaan, barang kemudian diserahkan kepada pembeli dan transaksi penjualan tunai kemudian dicatat oleh perusahaan. Berdasarkan sistem pengendalian yang baik, sistem penerimaan kas dari penjualan tunai mengharuskan (Mulyadi, 2016):

1. Penerimaan kas dalam bentuk tunai harus segera disetor ke bank dalam jumlah dengan cara melibatkan pihak lain selain kasir untuk melakukan internal check.

2. Penerimaan kas dari penjualan tunai dilakukan melalui transaksi kartu kredit, yang melibatkan bank penerbit kartu kredit dalam pencatatan transaksi penerimaan kas.

\subsection{Prosedur Sistem Penerimaan Kas dari Penjualan Tunai}

\subsubsection{Prosedur penerimaan kas dari over-the counter sales.}

(Mulyadi, 2016) dalam penjualan tunai ini, pembeli datang ke perusahaan, melakukan pemilihan barang atau produk yang akan dibeli, melakukan pembayaran ke kasir, dan kemudian menerima barang yang dibeli. Dalam over-the counter sales ini, perusahaan menerima uang tunai, cek pribadi (personal check), atau pembayaran langsung dari pembeli dengan credit card, sebelum barang diserahkan kepada pembeli.

\subsubsection{Prosedur penerimaan kas dari Cash On Delivery Sales (COD sales)}

(Mulyadi, 2016) Cash on delivery sales (COD sales) adalah transaksi penjualan yang melibatkan kantor pos, perusahaan angkutan umum, atau angkutan sendiri dalam penyerahan dan penerimaan kas dari hasil penjualan. COD sales merupakan sarana untuk memperluas daerah pemasaran dan untuk memberikan jaminan penyerahan barang bagi pembeli dan jaminan penerimaan kas bagi perusahaan penjual. 


\subsubsection{Prosedur Penerimaan Kas dari Credit Card Sales}

(Mulyadi, 2016) Sebenarnya credit card bukan merupakan suatu tipe penjualan Credit card merupakan sarana pembayaran bagi pembeli, baik dalam over-the-counter sales maupun dalam penjualan yang pengiriman barangnya dilaksanakan melalui jasa pos atau angkutan umum.

\subsection{Sistem Pengendalian Intern}

Sistem pengendalian intern meliputi struktur organisasi, metode dan ukuran- ukuran yang dikoordinasi untuk menjaga organisasi, mengecek ketelitian dan keandalan data akuntansi, mendorong efesiensi dan mendorong dipatuhinya kebijakan manajemen (Mulyadi, 2016). Unsur pokok sistem pengendalian intern yaitu: a. Struktur organisasi yang memisahkan tanggung jawab fungsional secara tegas, b. Sistem wewenang dan prosedur pencatatan yang memberikan perlindungan yang cukup terhadap kekeyaan, utang, pendapatan, dan biaya. c. Praktik yang sehat dalam melaksanakan tugas dan fungsi setiap unit organisasi. d. Karyawan yang mutunya sesaui tanggung jawab. 


\section{METODE PENELITIAN}

Pendekatan penelitian yang digunakan oleh peneliti dalam penyusunan skripsi ini adalah metode kualitatif menurut (Sugiyono, 2013) metode kualitatif adalah yang berlandaskan pada filsafat pospositivisme, digunakan untuk meneliti pada kondisi obyek yang alamiah, dimana peneliti adalah sebagai instrumen kunci, pengambilan sampel sumber data dilakukan secara purposive dan snowbaal, teknik pengumpulan dengan tringgulasi (gabungan), analisis data bersifat induktif/kualitatif, dan hasil penelitian kualitatif lebih menekankan makna dari pada generalisasi. Penelitian ini menggunakan metode kualitatif deskriptif.

\subsection{Jenis Data yang dipergunakan dalam penelitian ini adalah data primer dan data sekunder.}

a. Data primer merupakan data yang dikumpulkan oleh peneliti dengan cara langsung dari sumbernya. Data primer yang diperoleh penulis antara lain :

$>$ Hasil observasi penulis terhadap PT. Indomarco Prismatama (Indomaret Stadion Plandaan Kedungwaru Tulungagung)

> Hasil wawancara dengan pihak-pihak terkait khususnya mengenai sistem dan prosedur penjualan dan penerimaan kas.

b. Data sekunder merupakan data yang diperoleh dari perusahaan secara tidak langsung yang berupa informasi dari sumber tertulis yang diantaranya buku -buku literatur yang berhubungan dengan data primer.

3.2 Sumber data pada penelitian ini sumber data yang diperoleh oleh peneliti berasal dari internal perusahaan khususnya bagian kasir PT. Indomarco Prismatama (Indomaret Stadion Plandaan Kedungwaru Tulungagung). 


\section{HASIL PENELITIAN DAN PEMBAHASAN}

\subsection{Telaah Elemen Sistem Pengendalian Intern Penerimaan Kas Dari Penjualan}

Tunai PT. Indomarco Prismatama (Indomaret Stadion Plandaan Kedungwaru

\section{Tulungagung)}

\subsubsection{Elemen Organisasi}

Struktur organisasi yang memisahkan tanggung jawab fungsional belum secara tegas dilakukan. Masih terdapat tugas yang dapat dilakukan oleh semua fungsi. Sebagai contoh asisten kepala toko yang juga merangkap sebagai administrasi, pramuniaga yang juga merangkap menjadi kasir, dan merchandiser yang merangkap menjadi fungsi gudang.

\subsubsection{Elemen Sistem Otorisasi dan Prosedur Pencatatan}

Sistem otorisasi dan prosedur pencatatan yang memberikan perlindungan yang cukup pada gerai Indomaret telah dijalankan tetapi belum efektif. Catatan akuntansi yang digunakan oleh gerai Indomaret hanya catatan penjualan harian, dan kartu persediaan saja yang digunakan. Akibat hanya adanya catatan-catatan ini kurang dapat menjadi alat untuk pengawasan akuntansi terhadap operasi-operasi dan transaksi- transaksi yang ada dalam perusahaan.

\subsubsection{Elemen Praktik yang Sehat}

Pada gerai Indomaret terjadi perputaran jabatan sesuai dengan keputusan kantor pusat dan pemeriksaan secara mendadak dari kantor pusat yang dilakukan tanpa konfirmasi.Setiap bulan dilakukan pemeriksaan jurnal penjualan oleh supervisior area dengan kepala toko serta asisten kepala toko untuk membandingkan laporan keuangan pusat dengan laporan di gerai.

\subsubsection{Karyawan yang Mutunya Sesuai Tanggung Jawab}

Proses rekruitmen PT. Indomarco Prismatama dinilai dari beberapa kriteria, 
diantaranya : Tingkat pengalaman kerja, pendidikan terkahir, dan psikotest, training bulanan, trainingng 3 bulan sekali, training 6 bulan sekali.

\subsection{Penjelasan Bagan Alir Sistem Penerimaan Kas dari Penjualan Tunai PT.}

Indomarco Prismatama (Indomaret Stadion Plandaan Kedungwaru

\section{Tulungagung)}

\subsubsection{Bagian Kasir}

Menerima barang dari konsumen, mengoperasikan mesin register kas, menerima uang dari konsumen untuk transaksi pembayaran, mencetak pita register kas, memberikan pita register kas pada konsumen bersama barang, menghitung hasil penjualan diakhir shift, selanjutnya kasir mencetak slip penjualan, setelah itu kasir mencetak slip serah terima uang kas, slip penjualan dan slip serah terima uang kas diserahkan kepada kepala toko bersama uang.

\subsubsection{Kepala toko}

Menerima slip penjualan dan slip serah terima uang kas bersama uang, mencocokkan uang dengan slip penjualan dan serah terima uang kas, menarik dan mencetak data master dari sistem kantor pusat, membuat bukti setor toko sebanyak 3 lembar, bukti setor toko dan uang diteruskan ke kantor pusat bersama driver pengirim barang, data master dan Bukti Setor Toko lembar ketiga diarsip, slip penjualan, Slip Serah Terima Uang Kas, dan Bukti Setor Toko lembar kedua diserahkan ke asisten kepala toko

\subsubsection{Asisten Kepala Toko}

Menerima slip penjualan dari kepala toko dan mengarsipnya, Menyimpan uang hasil penjualan sebelum penyetoran ke kantor pusat, menerima slip serah terima uang kas per shift, menerima dan bukti setor toko dari kepala toko, menjurnal ke jurnal penerimaan kas dari penjualan, setelah melakukan penjurnalan slip penjualan, slip serah terima uang kas, dan bukti transfer barang kemudian diarsip, membuat laporan yang diperlukan terkait kegiatan toko. 
a. Merchandise

> Mengkoordinir permintaan barang dagangan dari distribution center.

$>$ Mengkoordinir pengeluaran atau retur barang dari toko ke distribution center.

$>$ Mengkoordinir pendisplay-an barang dagangan baik dirak-rak penjualan ataupun gudang.

$>$ Mengkoordinir dan memastikan sarana promosi terpasang sesuai petunjuk.

$>$ Menjaga dan merawat sarana promosi tersebut.

$>$ Menggantikan kepala toko atau asisten kepala toko apabila sedang off

b. Pramuniaga

$>$ Memberikan pelayanan kepada pelanggan.

> Melaksanakan kebersihan.

> Mempersiapakan sarana kerja yang diperlukan.

$>$ Melakukan pengawasan dan pencegahan barang hilang.

$>$ Menerima penitipan barang.

$>$ Melakukan proses transaksi penjualan langsung.

$>$ Pemajangan barang (display).

$>$ Persiapan retur barang. Informasi dan penawaran program promosi.

$>$ Pencetakan barang.

$>$ Penyebaran Leaflet.

$>$ Informasi barang kosong kepada MD atau kepala toko atau asisten kepala toko

\subsection{Evaluasi Sistem dan Prosedur Penerimaan Kas dari Penjualan}

\section{Tunai PT.Indomarco Prismatama (Indomaret Stadion Plandaan Kedungwaru}

\section{Tulungagung)}

Permasalahan yang sering dihadapi oleh PT. Indomarco Prismatama disebabkan sistem penjualan dan penerimaan kas yang masih lemah, antara lain sebagai berikut:

a. Dalam sistem dan prosedur penerimaan kas bagian asisten toko juga merangkap sebagai administrasi.

b. Sering terjadinya perbedaan antara harga di price list rak produk dengan POS (Point Of Sales).

c. Dalam melakukan penyetoran penerimaan kas dari penjualan tunai kepala toko biasanya menitipkan uang kepada driver pengirim barang bersama bukti setor toko. 
d. Perbedaan Slip penjualan dengan uang kas secara fisik dari penjualan tunai yang diterima

\subsection{INTEPRETASI}

\subsubsection{Usulan Pemecahan Masalah Sistem dan Prosedur Penerimaan Kas dari}

\section{Penjuala Tunia pada PT. Indomarco Prismatama (Indomaret Stadion Plandaan Kedungwaru Tulungagung)}

a. Memisahkan perangkapan tugas pada asisten toko dan administrasi karena dengan perangkapan tugas tersebut dapat menimbulkan kecurangan.

b. Bagian kasir harus melakukan update harga secara berkala setiap harinya, dan melakukan koordinasi dengan pramuniaga. Jika ditemukan perubahan harga jual, maka harga pada price tag di rak produk sama dengan Point Of Sales karena perubahan harga jual bisa berubah setiap waktu dari kantor pusat.

c. Kepala toko dalam melakukan penyetoran uang kas hasil penjualan ke kantor pusat melalui bank agar lebih efektif dan terjamin keamanannya.

d. Perbedaan antara slip penjualan dan kas yang diterima secara fisik tidak selalu minus terkadang bisa lebih besar dari yang tercantum pada slip penjualan. Maka dari itu jika terjadi kelebihan uang kas, sebaiknya dibuatkan pembukuan kas kecil dengan metode fluktuasi untuk mengganti uang kas yang kurang akibat kesalahan yang terjadi

\subsubsection{Penjelasan Bagan Alir Sistem dan Prosedur Penerimaan Kas dari Penjualan Tunai PT. Indomarco Prismatama (Indomaret Stadion Plandaan Kedungwaru Tulungagung)}

a. Bagian Kasir

Menerima barang dari konsumen, mengoperasikan mesin register kas, menerima uang dari konsumen sebagai transaksi pembayaran, mencetak pita register kas dan memberikannya pada konsumen bersama barang, melakukan update harga jual, jika ada perubahan harga jual bagian kasir mencetak laporan perubahan harga jual dan memberitahu bagian pramuniaga untuk mengubah label harga di rak produk, menghitung uang hasil penjualan per shift, menghitung uang 
hasil penjualan per shift, Mencetak slip penjualan dan serah terima uang kas, menyerahkan slip penjualan dan serah terima kas kepada kepala toko bersama uang

b. Kepala Toko

Menerima slip penjualan dan serah terima uang kas dari bagian kasir, mencocokkan jumlah uang dengan slip penjualan dan serah terima uang kas, menarik dan mencetak data master dari kantor pusat dan mengarsipnya, slip penjulan dan serah terima uang kas diterukan ke bagian administrasi, kepala toko mengisi bukti setor bank sebanyak 3 rangkap, menyetor penerimaan kas dari penjualan tunai ke bank, Bukti setor bank lembar ke 1 diserahkan ke bank bersama uang, dan lembar ke 2 diteruskan ke bagian administrasi sedangkan lembar ke 3 diarsip oleh kepala toko sebagai dokumen sumber

c. Bagian Administrasi

Menerima slip penjualan dan serah terima uang kas dari kepala toko, melakukan penjurnalan atas penerimaan kas dari penjualan tunai, selanjutnya slip penjualan dan serah terima uang kas diarsipkan sebagai dokumen sumber, bagian administrasi juga menerima bukti setor bank dari kepala toko, melakukan pencatatan atas bukti setor toko, selanjutnya bukti setor toko diarsipkan sebagai dokumen sumber.

d. Asisten Kepala Toko

Menyimpan uang hasil penjualan yang diterima dari kepala toko (kepala shift yang bertugas) sebelum dilakukan penyotaran dan membuat laporan kenaikan dan penurunan penjualan serta promosi yang berkaitan dengan kegiatan toko. 


\section{SIMPULAN}

Berdasarkan hasil penelitian terhadap pelaksanaan sistem informasi akuntansi penerimaan kas dari penjualan tunai PT. Indomarco Prismatama guna meningkatkan pengendalian intern, dapat disimpulkan bahwa: Sistem pengendalian intern penerimaan kas dari penjualan tunai pada PT. Indomarco Prismatama cukup baik dengan beberapa kekurangan dimana bagian yang terkait dalam prosedur penerimaan kas dari penjualan tunai masih terjadi adanya perangkapan tugas, perbedaan harga antara price list dan point of sales, dalam prosedur penyetoran penerimaan kas dari penjualan tunai kepala toko biasanya menitipkan uang kepada driver pengirim barang bersama bukti setor toko, prosedur ini kurang efektif serta dari segi keamanan juga sangat lemah. 


\section{SARAN}

Untuk lebih mengoptimalkan pekerjaan agar mendapatkan kualitas yang baik dalam operasional maka penulis menyarankan sebagai berikut: PT. Indomarco Prismatama, hendaknya memperbaiki sistem dan prosedur penerimaan kas dari penjualan tunai yang baik dan menyempurnakan struktur organisasi yang didukung adanya pengendalian intern memadai dengan jalan menambah beberapa fungsi atau bagian sehingga tidak akan terjadi perangkapan tugas guna menjalanka tugasnya, disamping itu juga memudahkan pimpinan untuk selalu tau karyawannya. 


\section{DAFTAR PUSTAKA}

Gesah, R., \& Prabowo, M. (2015). Universitas tulungagung fakultas ekonomi 2015.

Mulyadi. (2016). Sistem Akuntansi, Edisi Keempat. Salemba Empat.

Romney, M. B. and P. J. S. (2014). Accounting Information System. Salemba Empat.

Sugiyono. (2013). Penelitian Bisnis: Pendekatan Kuantitatif, Kualitatif, dan R\&D. Alfabeta.

Susanto, A. (2013). Sistem Informasi Akuntansi, -Struktur-PengendalianResiko-

Pengembangan, Edisi Perdana, . Lingga Jaya. 